\title{
ブロック理論による不連続性岩盤斜面の 安定性評価に関する基礎研究
}

\section{STABILITY ANALYSIS OF JOINTED ROCK SLOPE BY THE BLOCK THEORY}

\author{
吉中龍之進* - 山辺正** 藤田朝 雄*** \\ By Ryunoshin YOSHINAKA, Tadashi YAMABE and Tomoo FUJITA
}

\begin{abstract}
The block theory to analyze three dimensional stability problems of discontinuous rock masses is applied to the actual discontinuous rock slope. Taking into consideration that the geometrical information about discontinuities generally increases according to progressive steps of rock investigation in field, the method adopted for analysis is divided into following two steps ; 1) the statistical/probabilitical analysis using information from the primary investigation stage which mainly consists of that of natural rock outcrops, and 2) the deterministic analysis correspond to the secondary stage using exploration adits.
\end{abstract}

Keywords : rock slope, discontinuities, stability analysis, key block

\section{1.はじめに}

近年，岩盤の不連続性に関する問題は，地下空洞や斜 面，石油の地下備蓄や放射性廃棄物の地層処分などさま ざまな岩盤構造物を対象として注目されさまざまな観点 から研究されている，岩盤内には断層，節理，シームな ビの地質学的不連続面が多数存在し, 岩盤全体の力学的, 水理学的挙動に支配的な影響を与えている. 岩盤の地下 空洞や斜面において掘削で生ずる岩盤の異常な変形や破 壊は, 掘削による応力解放やその他の影響で既存の不連 続面に生ずる変形やすべりによるところが大きいが，取 り分け不連続面で形成される不安定な岩塊の崩落や滑落 は重大な問題を生ずる。

岩盤の挙動解析は, 従来から有限要素法等で行われて きたがそのほとんどは岩盤の構造性を二次元と仮定する 解析である. しかし, 実際の不連続面は複雑な三次元分 布であるため不連続面の三次元性に支配された岩盤挙動 を評価することは難しい.

* 正会員 工博 埼玉大学教授 工学部建設基礎工学科 （テ338 浦和市下大久保 255）

** 正会員 工博 埼玉大学助教授 工学部建設基礎工学科 (同上)

*** 正会員 工修 動力炉・核燃料開発事業団東海事業所 ( $\overline{\mathrm{T}} 319-11$ 茨城県那珂郡東海村)
Goodman と Shi ${ }^{1)}$ は, 不連続面の幾何学的条件と力 学的条件が与えられれば掘削で危険となる岩塊をみつけ 出すことのできるブロック理論を体系化した.この岩塊 (ブロック) が, 落下あるいは滑動することによって岩 盤構造物が不安定となり，ある場合に周辺岩盤に進行性 破壊が生ずる可能性がある。このようなブロックをキー ブロックとよび, そのブロックに最適な支保を与えるこ とで合理的に岩盤全体の安定を図ろうとするのがキーブ ロック解析である.

ブロック理論1) は体系化されて間もない新しい解析方 法であるため, その適用性に関する研究 ${ }^{2), 31}$ が盛んに行 われているが，実際の岩盤施工に適用した例はほとんど ない. 理論の実用化のためには多くの課題があろうが, 中でも不連続面の取扱いは重要である. 本研究は実際の 岩盤斜面を対象として, 不連続面データの取り方や整理 方法との関連からキーブロック解析の適用方法を考察す るものである.なお，本研究ではキーブロックの同定を はじめとするすべての計算を通常の 16 bit パーソナルコ ンピュータで実施し, 現場で容易に適用できるシステム を構成できるよう心掛けた。

\section{2. 岩盤調査の段階とキーブロック解析の適用}

岩盤調査, 特に不連続面に関する調査データの量と質 
は調査の段階に応じて変化する．したがって不連続面の 分布を基本データとするブロック解析では，このような 調查段階の変化に対応した適用が必要と考えられる.

Fig. 1 は岩盤調査を 3 段階に大別し，それぞれの段階で のブロック理論の利用の位置づ(4),5)を示したものであ る.ここで $\mathrm{B}$ および $\mathrm{KB}$ はブロックおよびキーブロッ クを示し, 下線はそれぞれの調査段階で明らかになる項 目である.

(1)岩盤露頭調査を主とする段階は, 岩盤内部の掘削部 分の不連続面のデー夕を直接計測できない，そのため不 連続面分布に関する統計的諸量を用いてブロック理論を 適用することになる．したがって，不連続面分布の諸量 を表わすための確率モデルの妥当性の検討が重要であ る.このようなデータを用いるキーブロック解析の結果 は, ブロックの平均的な形状・寸法を求めるので計画構 造物の方向性や支保の検討に利用できる，(2)横坑やボー リング調查を主とする段階(6)では岩盤内部の調査が行わ れるので, 先のデータにさらに不連続面分布の三次元的 な空間的位置の情報が加わる。したがって, ブロックの 具体的な形状・寸法・分布位置が推定でき，より進んだ 設計に利用できる. (3)施工時の調査段階は, 直接に岩盤 の掘削面が観察できるので危険ブロックの決定とその対 策が議論される.

本文では，(1)を統計的/確率論的解析，(2)および(3)を 確定論的解析とよぶこととし，(2)の段階の考え方を中心 に述べる. また, 最後の部分で(2)と(1)の解析結果の比較 を述べる.

確定論的解析に必要な不連続面の情報は，調査坑の三 次元的な分布位置とそこで観察した不連続面の分布位置 である. 不連続面の分布位置の三次元的な評価，不連続 面の連続性の仮定，および計画掘削面の設定が必要であ る．計画掘削面にブロック理論を適用することにより危

1. 岩笽露頭娚查段㳻

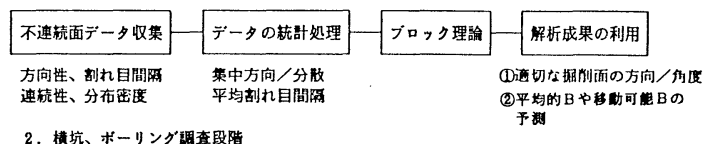

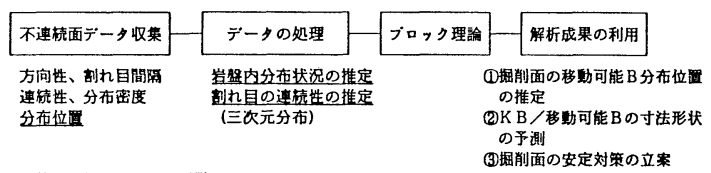

3. 施工時擗削面の調查即暗

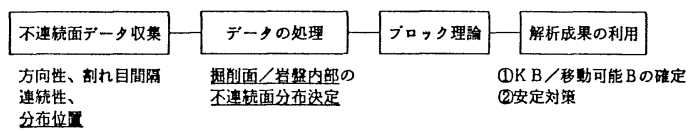

Fig. 1 Application of block theory to the stability of rock slope corresponding to the exploration stage.
険な移動可能ブロックの分布位置と規模が求まる. 本文 では計画掘削面上での不連続面トレースマップの評価の 方法, トレースマップから移動可能ブロックを求める計 算プログラムの基本的な考え方を示す.

\section{3. 計画掘削面における不連続面分布の推定}

調査横坑で観察した断層および節理その他の不連続面 の分布状態から計画掘削面における不連続面分布を推定 し，その結果に基づいて移動可能ブロックを検索する.

対象とする岩盤の範囲内に不連続面がどのように分布 するかを決定することは, 岩盤工学における最も難しい 問題の 1 つである．統計的あるいは確率論的な予測は， 必要なサンプルの量的条件が満たされれば，かなりの精

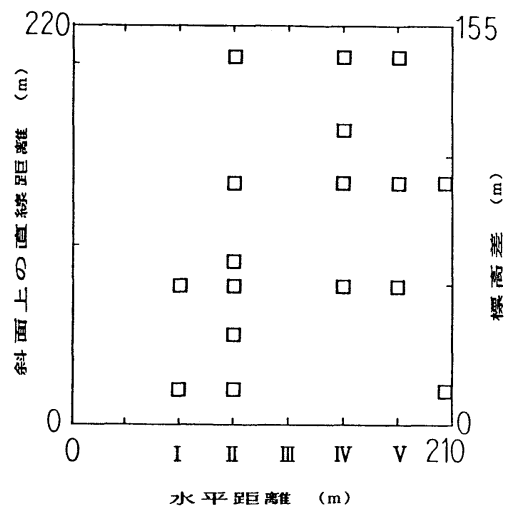

Fig. 2(a) Arrangement of exploratory adits on predicted excavation surface.

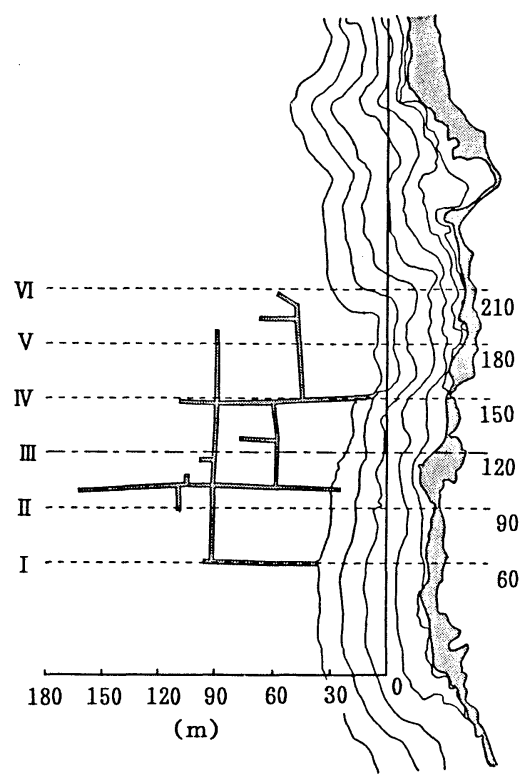

Fig. 2(b) Plan view of exploratory adits at $300 \mathrm{~m}$ above sea level. 
度で判断することが可能である. しかし，個々の問題が 起こる事象を特定するためには, サンプリングは量のみ ならず質的にも充実されなければならない.しかし，現 実問題としてサンプリングには限界があるので，判断が 要求されるそれぞれの段階においてその段階の評価に含 まれる誤差, 特性を考慮しつつ工学的判断を加味しつつ 対処することが必要であろう.

本節の確定論的解析の条件を設定するためには, 以上 の考慮が必要である. 計画掘削面における不連続面分布 の推定精度は, 横坑の空間的配置 (配置間隔, 配置方向) や不連続面の評価精度（連続性，分布間隔）に基本的に 依存している。 まず，実例を対象にこれらの影響を考察 する.

岩盤はチャートから成る新鮮かつ不連続性の硬岩であ る. Fig. 2(a) は, 任意の計画掘削面に分布する調査横 坑の配置の例である.ここで計画掘削面は, 縦 $220 \mathrm{~m}$, 横 $210 \mathrm{~m}$, 方向は傾斜方位 $/$ 傾斜 $=105^{\circ} / 45^{\circ}$ とした. 調 査横坑はおよそ縦横約 $30 \mathrm{~m}$ の間隔で配置されている.

Fig. 2(b) はFig. 2(a) のある標高での横坑分布の水平 断面図である. 図中の太線を座標軸とし, 点 0 を原点と した. また，I〜VIの線は測線を表わし，この線に沿っ て他の標高の調査横坑が配置されている. 不連続面に関 するデータは，この横坑の調査データから読み取る.

\section{（1）横坑の空間的配置 - 配置間隔・配置方向}

現状では横坑は一般に他の調査指針等に基づいて設定 されているので, 本研究では横坑の空間的配置（位置, 間隔，方向）は所与の確定的条件である.

\section{（2）不連続面の間隔}

一般に不連続面の間隔は横坑内で計測可能である。調 査から分布関数形, 平均間隔, 最大值等の情報が得られ る. 解析の対象とした岩盤の不連続面間隔は各横坑から 求まる. この場合, 測線の $\mathrm{I} \sim \mathrm{V}$ 上の各横坑展開面から, 基準線を切る不連続面の間隔を求める.ここでは各調査 坑では坑内に向かって右上隅を基準線にする. 計測した 不連続面間隔の分布をFig. 3(a)〜 (e) に，また同図に 分布関数を負の指数分布としたときの結果を示してい る.

$$
f(X)=\frac{1}{u} \exp (-X / u)
$$

ここで， $X$ は間隔， $u$ はその平均值を表わしている. 各データとも負の指数分布に適合することがわかる. 平 均值は約 2〜 $4 \mathrm{~m}$ である.

\section{（3）不連続面の連続性}

不連続面の連続性に関する情報を得るためには, 計画 掘削面の位置で詳細な岩盤調査を行うか, あるいは近傍 で同じ岩種と岩質の岩盤の大きな露頭における調査が必 要である.しかし，多くの場合このような条件を満たす

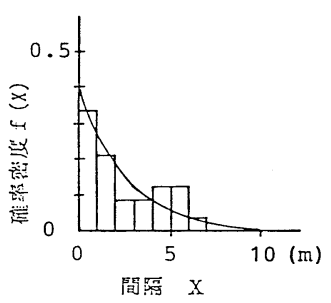

(a) I -line $u=2.58 \mathrm{~m}$

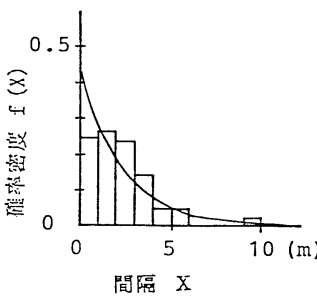

(c) $\quad N$-line $u=2.24 \mathrm{~m}$

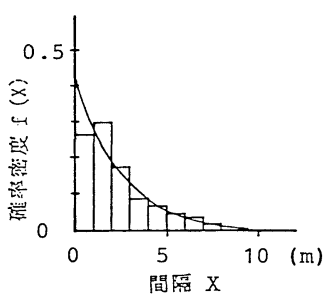

(b) II -line $u=2.34 \mathrm{~m}$

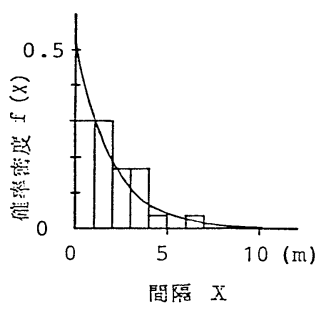

(d) V-line $u=1.90 \mathrm{~m}$

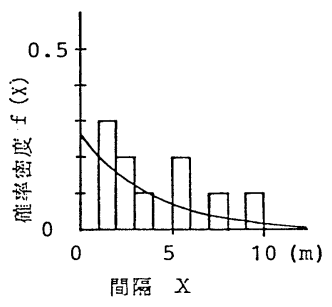

(e ) V-line $u=3.83 \mathrm{~m}$

Fig. 3 Probability density $f(x)$ vs. spacing $x$ of discontinuities.

ことは困難であるので不連続面の連続性に関する精度の 高いデータを求めることは難しい. したがって, 不連続 面の性質や性状からある仮定を設けて工学的な判断を加 えなければならない.本研究においても同様であるので, 次の条件を設けることとした。

(1) 不連続面は平面で, i ) 断層と ii ) その他の不連 続面（節理，シーム）に分かれる.

(2) 横坑で連続性を追跡できるものについては，その 情報を用いる。

(3) (2)以外の断層は解析領域内では連続するものとす る.

(4) (2)以外のその他の不連続面は, 横坑の断面を完全 に横切るものについてのみ考虑し, その広がりは横坑位 置を中心とする円盤とする. 円盤の大きさは, 高角度の 不連続面が地表から深部まで及んでいることを考慮し 40〜80 m と仮定しパラメータースタディを行う.

以上の条件のもとで求めた各半径に対応する計画掘削 面の不連続面トレースを Fig. 4(a)〜 (e) に示す.また， 解析の概念図をFig. 5 に示す。上記卜レースの妥当性を 


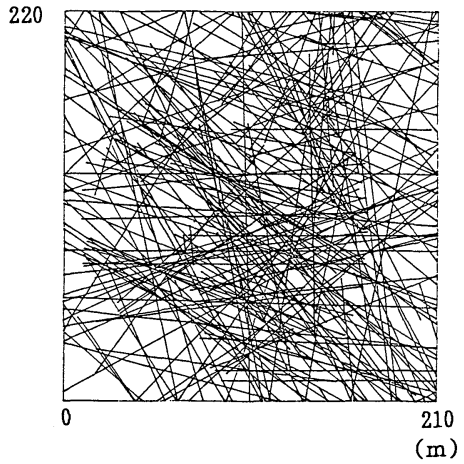

(a) $r=80 \mathrm{~m}$, number of traces $=216$

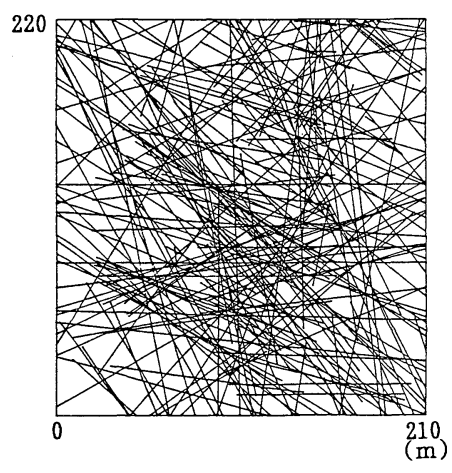

(b) $\quad r=70 \mathrm{~m}$, number of traces $=213$

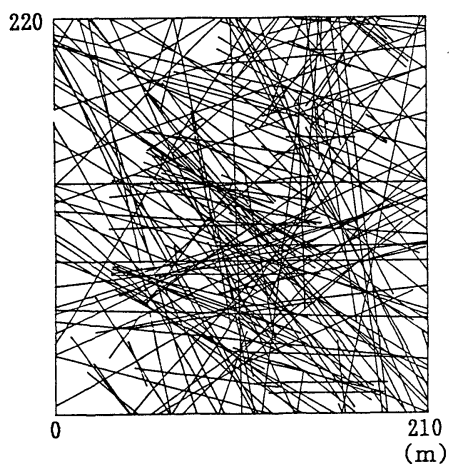

(c) $\quad r=60 \mathrm{~m}$, number of traces $=209$

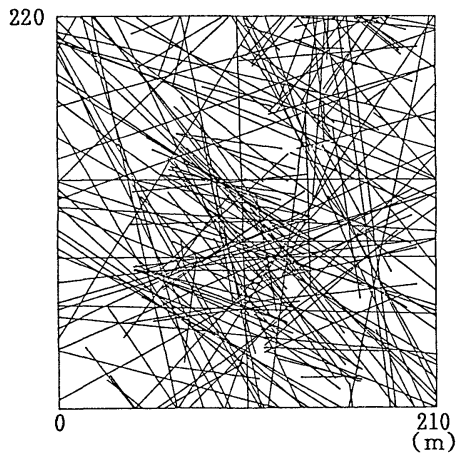

(d) $r=50 \mathrm{~m}$, number of traces $=199$

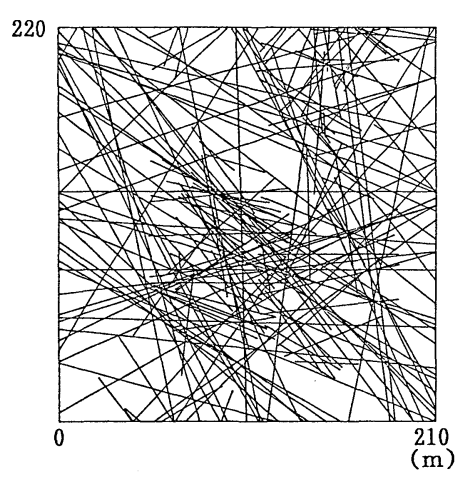

(e ) $\quad r=40 \mathrm{~m}$, number of traces $=187$

Fig. 4 Predicted traces of discontinuities on excavated surfaces.

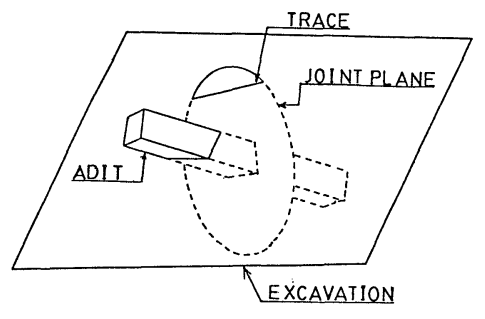

Fig. 5 General view of the predicted excavation surface.

検討するため掘削面に向かって左下を原点として, 水平 方向を $X$ 軸，斜面方向を $Y$ 軸とし， $X=105 \mathrm{~m} ， Y=$ $110 \mathrm{~m}$ の位置に各 1 本のスキャンラインを設け不連続面 の分布間隔を調べた．その結果，いずれの場合も分布間 隔は負の指数分布に従うことがわかった（2) で求め た不連続面の分布間隔は上述のパラメータースタディの 結果, 不連続面の半径を $50 \mathrm{~m}$ とすることで説明できる. したがって,この結果からその他の不連続面の半径が $50 \mathrm{~m}$ の場合を計画掘削面とする.

\section{4. ブロック理論への適用}

\section{（1） トレースマップ上での移動可能性ブロックの検 索}

トレースマップにおける移動可能ブロックの検索につ
いては, Chan, Goodman )によって提案されている. 彼らは，ブロックを構成するトレースをベクトル化して 表わす“方向図”を作成して, ブロックの移動可能性を 判定している.この方法はブロックの移動可能性の判定 の簡便法といえる．原理的には各ブロックの JP（ジョ イントピラミッド：ブロックを構成する不連続面を任意 の一点に平行移動したもの), BP (ブロックピラミッ ド：ブロックを構成するすべての面を任意の一点に平行 移動したもの）の連立不等式を解くことと等価である. この方法では, トレースマップ上でいく本かのトレース でブロックを構成する閉領域と，ブロックコードの情報 があることを前提にしている.本研究では新たに,ブロッ クを構成する閉領域の決定法と, ブロックコードの決定 法を含めたトレースマップ上での移動可能ブロックの検 索法を示す．また，ブロックを作る面の増加に伴う移動 方向の制限と, コンピュータプログラムの効率化を考え, 対象とする閉領域を三角形と四角形に限定する. 以下(1) （3)に，その手順を示す.

(1) 閉領域は，トレースの交点により定まるので，卜 レース内に他のトレースとの交点が存在するか否かを判 定しなければならない。ここで, トレースは, 掘削平面 内で $\left(x_{i 0}, y_{i 0}\right)$ と $\left(x_{i 1}, y_{i 1}\right)$ のように $X Y$ 座標で与えられ る.よってトレースの方程式は次のように表わされる. 


$$
\left.\begin{array}{l}
X=\left(x_{i 1}-x_{i 0}\right) t_{i}+x_{i 0} \\
Y=\left(y_{i 1}-y_{i 0}\right) t_{i}+y_{i 0}
\end{array}\right\}
$$

$t_{i}$ は媒介変数を表わす.

また，他のトレースを $\left(x_{j 0}, y_{j 0}\right)$ と $\left(x_{j 1}, y_{j 1}\right)$ とすると きトレース $i, j$ の交点は, 次式で与えられる.

$$
\left[\begin{array}{ll}
\left(x_{i 1}-x_{i 0}\right) & \left(x_{j 0}-x_{j 1}\right) \\
\left(y_{i 1}-y_{i 0}\right) & \left(y_{i 1}-y_{i 0}\right)
\end{array}\right]\left\{\begin{array}{c}
t_{i} \\
t_{j}
\end{array}\right\}=\left\{\begin{array}{l}
\left(x_{j 0}-x_{i 0}\right) \\
\left(y_{j 0}-y_{i 0}\right)
\end{array}\right\}
$$

よって交点が各トレース内に存在するための条件は， $0 \leqq t_{i} \leqq 1 \quad$ かつ $0 \leqq t_{j} \leqq 1$

(2) 対象を凸形ブロックとするので， 凹形ブロックの 除去とブロックコードの決定を行う．そのためには，ま ず不連続面を平面の式で三次元的に表わさなければなら ない.Fig. 6(a) は掘削面上にある任意の一点 $\mathrm{P}$ を次 元的に表わしている.

掘削面上での座標を $(x, y)$ とし掘削面の方向を, 傾斜 方位 $/$ 傾斜 $=(\alpha / \beta), \mathrm{P}$ 点の三次元座標を $(X, Y, Z)$ とす ると次のように $Z$ 座標が求まる.

$$
\begin{aligned}
& O Q=x, \quad P Q=y, \quad \angle P Q P^{\prime}=\beta \\
& P^{\prime} Q=P Q \cos \beta=y \cos \beta \cdots \cdots \cdots \cdots \cdots \cdots \cdots \cdots \cdots \cdots \cdots \cdots \cdots \cdots \\
& Z=P Q \sin \beta=y \sin \beta \cdots \cdots \cdots \cdots \cdots
\end{aligned}
$$

Fig. 6(b) は， $Z$ 軸方向からみた図である.

$$
\begin{aligned}
& a=\angle P^{\prime} O Q=\tan ^{-1}\left(\frac{Q P^{\prime}}{O Q}\right)=\tan ^{-1}\left(\frac{y \cos \beta}{x}\right) \\
& \text {............................. ( } 7 \\
& b=\angle S O P^{\prime}=\alpha-90-a \\
& O P^{\prime}=\left(O Q^{2}+Q P^{\prime}\right)^{0.5}=\left(x^{2}+y^{2} \cos ^{2} \beta\right)^{0.5}
\end{aligned}
$$

よって, $X, Y$ 座標は, 次式で示される.

$$
\begin{aligned}
X & =O R=O P^{\prime} \sin b \\
& =-\left(x^{2}+y^{2} \cos ^{2} \beta\right)^{0.5} \cos \left(\alpha-\tan ^{-1}\left(\frac{y \cos \beta}{x}\right)\right) \\
Y & =O S=O P^{\prime} \cos b \\
& =\left(x^{2}+y^{2} \cos ^{2} \beta\right)^{0.5} \sin \left(\alpha-\tan ^{-1}\left(\frac{y \cos \beta}{x}\right)\right)
\end{aligned}
$$

ここで不連続面の方向を傾斜方位 $/$ 傾斜 $=(\alpha / \beta)$ とする とき単位法線ベクトルは，次のように表わされる.

$$
\begin{aligned}
& \hat{n}=(\sin \beta \cdot \sin \alpha, \quad \sin \beta \cdot \cos \alpha, \quad \cos \beta) \\
& =(A, B, C) \text {. }
\end{aligned}
$$

ここで $x$ を原点から不連続面上の任意の点への位置べ クトル $\boldsymbol{x}=(X, Y, Z)$ とし, $D$ を不連続面と原点との距 離とすると各不連続面の方程式は各位置ベクトル成分に よって座標形式で表わすことができる.

$$
A X+B Y+C Z=D
$$

得られた三次元座標と式 (12) で求めた不連続面の単位 法線ベクトルより, 式 (13) を用いて原点との距離 $D$ が求まる.

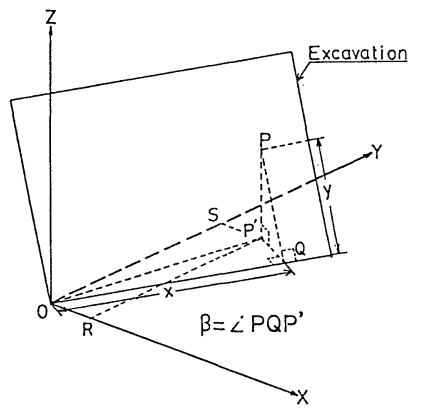

Fig. 6(a) Three dimensional representation of a point on the excavated surface.

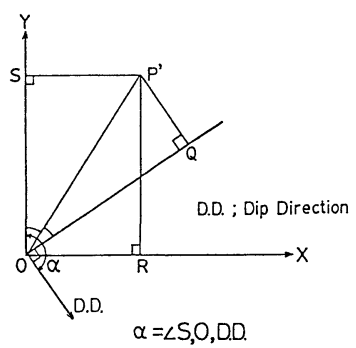

Fig. 6(b) Projection of a point in Fig. 6(a) on $X-Y$ plane.

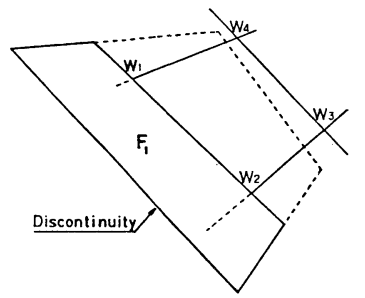

Fig. 7(a) Determination of block code.
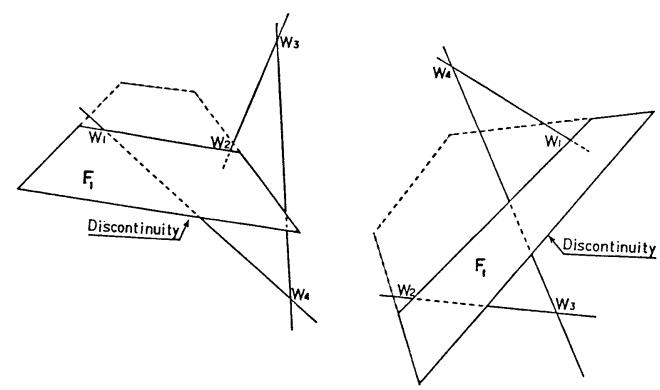

Fig. 7(b) Concave biock.

Fig. 7(c) Closed region not defined block.

Fig. 7 は, 四角形閉領域の不連続面の位置と他の交点 の関係を示している. 注目する不連続面 $F_{1}$ が形成する 凸ブロックの半空間は，不連続面上にないトレースの 2 交点が同時に 1 つの半空間を定義する場合に決定され る.もし, 同時に 2 つの半空間が Fig. 7(b), (c) のよう 
に定義されたならそのブロックは，凹形ブロックかまた はブロックを構成しない，注目する不連続面の式を式

（13）で表わせば,

$$
A_{i} X+B_{i} Y+C_{i} Z=D_{i}
$$

となりこの不連続面上にないトレースの 2 交点を $\left(X_{1}, Y_{1}, Z_{1}\right),\left(X_{2}, Y_{2}, Z_{2}\right)$ とするとき，上半空間ならば 次式を満たす.

$$
\begin{aligned}
& A_{i} X_{1}+B_{i} Y_{1}+C_{i} Z_{1} \geqq D_{i} \\
& A_{i} X_{2}+B_{i} Y_{2}+C_{i} Z_{2} \geqq D_{i}
\end{aligned}
$$

このときブロックのコードは，“0’となる．また，下半 空間のとき

$$
\begin{aligned}
& A_{i} X_{1}+B_{i} Y_{1}+C_{i} Z_{1} \leqq D_{i} \\
& A_{i} X_{2}+B_{i} Y_{2}+C_{i} Z_{2} \leqq D_{i}
\end{aligned}
$$

このときブロックのコードは, '1'となる.

Fig.7(a) において注目する不連続面を $F_{1}$ とし，こ の不連続面と他のトレースとの交点を $W_{1}, W_{2}, F_{1}$ 上に ない他のトレースの交点を $W_{3}, W_{4}$ とする. $W_{3}, W_{4}$ と も上半空間に属すので $F_{1}$ のブロックのコードは' '0’ と なる．また，式（15）および式（16）も満たす.

Fig. 7(b) の凹形ブロックで， $W_{3}$ は上半空間， $W_{4}$ は 下半空間となり，上述の条件を満たさない．Fig. 7(c) の場合も， $W_{3}$ は下半空間， $W_{4}$ は上半空間となり，この 場合は，ブロックを構成しない。また，三角形閉領域に ついては，不連続面を構成しない点が一点となるため, 凹形ブロックは出現しない。ささらにブロックのコードの 決定も，四角形閉領域と同様にして求められる.

以上のようにして，凸形ブロックとそのブロックコー ドが求められる.

(3) ブロックの移動可能性の判定を行う. 本研究では, トレースベクトルを用いた方向図は用いず，次のような 数学的簡便法で移動可能性を判定する [参考文献 1 ), 6 章参照].

一般にブロックの移動可能性については，ステレオ投 影法を用いた視覚的方法で判定できる．しかし実際には 多くのデー夕を処理しなければならないため, 簡便かつ 迅速な方法を考えなければならない。よって本研究にお いては，ベクトル法を用いたブロックの移動可能性の判 定方法を用いる.

Table 1 のデータと先に述ベたブロックのコードで表 現した任意のブロック 01011 を用いる.JP は，

$$
\begin{aligned}
& A_{1} X+B_{1} Y+C_{1} Z \geqq 0 \\
& A_{2} X+B_{2} Y+C_{2} Z \leqq 0 \\
& A_{3} X+B_{3} Y+C_{3} Z \geqq 0 \\
& A_{4} X+B_{4} Y+C_{4} Z \leqq 0
\end{aligned}
$$

$\mathrm{EP}$ (掘削ピラミッド：ブロックを構成する自由表面を 任意の一点に平行移動したもの）は,

$$
A_{5} X+B_{5} Y+C_{5} Z \leqq 0
$$

Table 1 List of orientation of slope and joints, and friction angle of joints.

\begin{tabular}{|c|c|c|c|}
\hline 不連䌇面 & 傾斜方位 & 傾斜 & 摖角 \\
\hline \hline P 1 & $105^{\circ}$ & $45^{\circ}$ & $40^{\circ}$ \\
\hline P 2 & $235^{\circ}$ & $70^{\circ}$ & $30^{\circ}$ \\
\hline P 3 & $195^{\circ}$ & $12^{\circ}$ & $25^{\circ}$ \\
\hline 自由表面 & $185^{\circ}$ & $65^{\circ}$ & - \\
\hline
\end{tabular}

Table 2 Direction cosines of normals to joint planes and free surfaces.

\begin{tabular}{|c|c:c:c|}
\hline 面 & $X$ & $Y$ & $Z$ \\
\hline 1 & 0.433013 & -0.250000 & 0.866026 \\
\hline 2 & 0.620885 & 0.739942 & 0.258820 \\
\hline 3 & -0.241843 & -0.664463 & 0.707107 \\
\hline 4 & -0.492405 & 0.413174 & 0.766045 \\
\hline 5 & 0.000000 & -0.866025 & 0.500000 \\
\hline
\end{tabular}

Table 3 Combination of half space.

\begin{tabular}{|rr|rrrrr|}
\hline \multirow{2}{*}{$\mathrm{I}$} & \multirow{2}{*}{$\mathrm{J}$} & \multicolumn{6}{|c|}{$\mathrm{K}$} \\
\cline { 3 - 7 } & & 1 & 2 & 3 & 4 & 5 \\
\hline \hline & 2 & 0 & 0 & 1 & 1 & -1 \\
1 & 3 & 0 & -1 & 0 & -1 & 1 \\
1 & 4 & 0 & -1 & 1 & 0 & 1 \\
1 & 5 & 0 & 1 & -1 & -1 & 0 \\
2 & 3 & 1 & 0 & 0 & -1 & 1 \\
2 & 4 & 1 & 0 & 1 & 0 & 1 \\
2 & 5 & -1 & 0 & -1 & -1 & 0 \\
3 & 4 & -1 & -1 & 0 & 0 & -1 \\
3 & 5 & 1 & 1 & 0 & 1 & 0 \\
4 & 5 & 1 & 1 & -1 & 0 & 0 \\
\hline
\end{tabular}

Table 4 Testing matrix.

\begin{tabular}{|rr|rrrrr|}
\hline \multirow{2}{*}{$\mathrm{I}$} & \multirow{2}{*}{$\mathrm{J}$} & \multicolumn{6}{|c|}{$\mathrm{K}$} \\
\cline { 3 - 7 } & & 1 & 2 & 3 & 4 & 5 \\
\hline 1 & 2 & 0 & 0 & 1 & -1 & 1 \\
1 & 3 & 0 & 1 & 0 & 1 & -1 \\
1 & 4 & 0 & 1 & 1 & 0 & -1 \\
1 & 5 & 0 & -1 & -1 & 1 & 0 \\
2 & 3 & 1 & 0 & 0 & 1 & -1 \\
2 & 4 & 1 & 0 & 1 & 0 & -1 \\
2 & 5 & -1 & 0 & -1 & 1 & 0 \\
3 & 4 & -1 & 1 & 0 & 0 & 1 \\
3 & 5 & 1 & -1 & 0 & -1 & 0 \\
4 & 5 & 1 & -1 & -1 & 0 & 0 \\
\hline
\end{tabular}

となる，有限性定理，移動可能性定理を集合論の形式で 表わせば次のようになる.

$$
\mathrm{BP}=\mathrm{JP} \cap \mathrm{EP}=\phi \text {. }
$$

$$
\mathrm{JP} \neq \phi
$$

よって, 式 (21)，(22）を満たす解が存在すればブロッ クは移動可能といえる. しかし，このようなベクトル方 程式を使用する解析より，計算時間を短くする数学的簡 便法を使用した方がプログラム化するのに適している.

式（12）を用いて面の単位法線ベクトルの座標を計算 した結果を Table 2 に示す．半空間の組合せを次式で定 義する. 
$\boldsymbol{I}_{k}^{i j}=\operatorname{sign}\left[\left(\hat{n}_{i} \times \hat{n}_{j}\right) \cdot \hat{n}_{k}\right]$

ここで, $\operatorname{sign}(x)=1 \quad(x>0)$

$$
\begin{array}{rr}
0 & (x=0) \\
-1 & (x<0)
\end{array}
$$

Table 2 から計算された $\boldsymbol{I}_{k}^{i j}$ の值を Table 3 に示す. この表を利用して積集合が空集合か否かを決定する.ブ ロックコード $\left(D_{B}\right)$ で表わされる半空間の積集合で構成 される特定のブロックを考える. 実例の場合 $D_{B}=$ (01011)

a) ブロックコード $\left(D_{B}\right)$ を選ぶ

$D_{B}=\left(\begin{array}{lll}a_{1} & a_{2} \cdots a_{m}\end{array}\right)$

b) 選ばれた $D_{B}$ について以下に定義されるように $a_{i}$ を $\boldsymbol{I}\left(a_{i}\right)$ に変換することによって得られる符号化された ブロックコード $\left(D_{S}\right)$ を決定する.

$$
\begin{array}{rll}
I\left(a_{i}\right)=+1 & \text { if } & a_{i}=0 \\
-1 & \text { if } & a_{i}=1 \\
0 & \text { if } & a_{i}=2 \\
\pm 1 & \text { if } & a_{i}=3
\end{array}
$$

よって

$$
D_{s}=\left(\boldsymbol{I}\left(a_{1}\right), \boldsymbol{I}\left(a_{2}\right), \cdots \boldsymbol{I}\left(a_{m}\right)\right)
$$

なお， $a_{i}=2$ と $a_{i}=3$ は，おのおのその不連続面を用い ない場合, 繰り返し用いる場合を意味する.

c) 式 (24) で定義した $\boldsymbol{I}_{k}^{i j}$ を用いて, $i, j$ の組合せ によるブロック $D_{B}$ に対応する考查マトリックス $\left(\boldsymbol{T}^{i j}\right)$ (testing matrix) を作る. $\boldsymbol{T}^{i j}$ は $\boldsymbol{I}_{k}^{i j} と \boldsymbol{I}\left(a_{i}\right)$ の積による $n$ 行のマトリックスである.

$$
\boldsymbol{T}^{i j}=\left(\boldsymbol{I}_{1}^{i j} \cdot \boldsymbol{I}\left(a_{1}\right), \boldsymbol{I}_{2}^{i j} \cdot \boldsymbol{I}\left(a_{2}\right), \cdots \boldsymbol{I}_{m}^{i j} \cdot \boldsymbol{I}\left(a_{m}\right)\right)
$$

実例の場合の考査マトリックスを Table 4 に示す.

d）有限性の判定

もし $(\boldsymbol{T})$ の各行が正と負の両方を含めば， $(\boldsymbol{T})$ に対応 するブロック $D_{B}$ は, 有限である. つまりその BP は, 空集合である，逆にいうと，もし $(\boldsymbol{T})$ の各行が正だけか または負だけならば， $(\boldsymbol{T})$ に対応するブロック $D_{B}$ は, 無限であり，その BP は空集合ではない.

以上の方法で各ピラミッドの積集合が判定できるの で，次のような方法で移動可能性を判定する．まず, BP での有限性を判定し, 次に JP で移動可能性を判定 する. その結果 BP での解析が空集合で, JP での解析 が空集合でないならば, そのブロックは移動可能であり, JP が空集合のときは，先細りブロックになる．また， $\mathrm{BP}$ での解析が空集合でない場合は, 無限ブロックにな る. 以上の流れのフローチャートを Fig. 8 に示す. 実例 の場合, 掘削面を加えたときには, 各行とも正と負の值 を含むので, BP は空集合となる，また，掘削面である 面 5 のデータを考慮しないで考査マトリックス (Table 4 ) をみると, $(i, j)=(1,3),(1,4),(2,3),(2,4)$ の とき正または負の值なので JP は, 空集合ではない.よっ

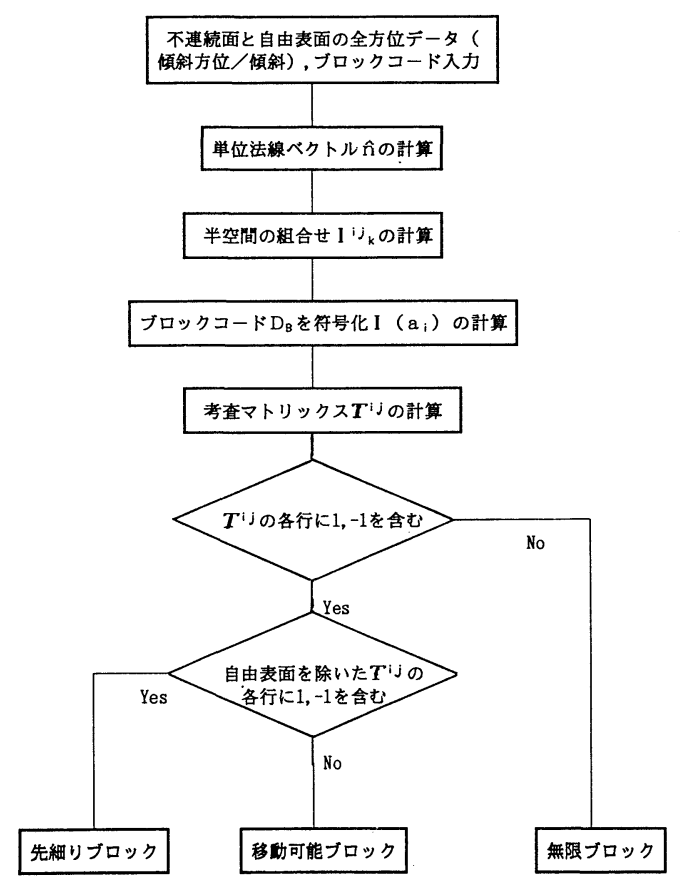

Fig. 8 Mathematical approach to classify the removability of blocks.

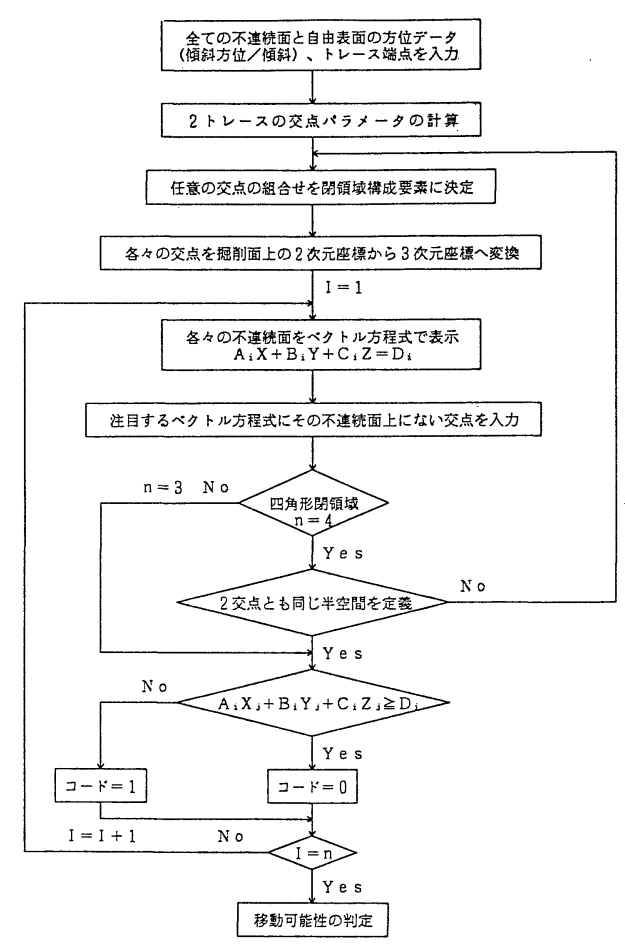

Fig. 9 Flow chart to determine the removable blocks from the trace map. 
て，ブロック 01011 は，移動可能ブロックとなる. 全体の流れをFig. 9 に示す.

\section{（2）解析方法および結果}

ブロックは,不連続面に囲まれた閉領域が対象となり， この計画掘削面を決定するにあたり多くの仮定を含んで いる. その他の不連続面のトレース長さ, 横坑配置の偏 りによる計画掘削面への不連続面トレース数の偏りなよ゙ はその支配的な要素である。したがって，計画掘削面に おける不連続面のトレースの解釈には，予想精度と工学 的問題としての配慮が必要である.

不連続面分布の予測精度亡不連続面間隔の実測結果を 考慮して，対象とすべきブロックの大きさを限定する. 計画掘削面に現われる小寸法のブロックほど，分布の予 測精度に疑問がある.しかし，その具体的寸法を定める ことは困難である. そこで，不連続面の平均間隔が 2 $4 \mathrm{~m}$ の範囲にあるという結果を参考にして，その下限値 以下は除外できるものとする.

また，同様に不連続面の最大間隔の分布は，約 $10 \mathrm{~m}$ であったことを考慮して，最大ブロックを $10 \mathrm{~m}$ とする. しかし,複合ブロックの存在も考慮する必要があるので, ブロックの大きさに関する解析を次のように行う。

(1) 計画掘削面に現われる閉領域を構成する不連続面 のトレースの平均值が，2〜10 $\mathrm{m}$ の範囲にあるブロック を検索する.

(2) (1)の大きさのブロックによる破壊よりも，大規模 な破壊として，計画掘削面に現われる閉領域を構成する 不連続面のトレースの平均值が， $10 \sim 30 \mathrm{~m}, 30 \sim 50 \mathrm{~m}$, 50 ７0 m， $70 \mathrm{~m}$ 〜の範囲にあるブロックを検索する. 求められた閉領域に対して，ブロック理論を適用し幾何 学的に移動可能なブロックを検出する. 求められた移動 可能ブロックに対して，合力を鉛直下向きにとり，すべ りモードおよび移動方向を求め, 移動方向が SP (スペー スピラミッド：EPの補集合）に含まれないものを対象 から除外する、ここまで残ったブロックに対して摩擦角 を $45^{\circ}$ にとり，安全率を求める。安全率が，1.5 以下の ブロックを危険な移動可能ブロックとする.

Fig. 10 に(1)の，Fig. 11 に(2)の $70 \mathrm{~m}$ の場合の解析結 果を示す. 塗りつぶされた閉領域が危険な移動可能ブ ロックとなる．また，Table 5 に(1)の個々のブロックの 情報を示す，表の項目の “不連続面”で方向の後の $(\mathrm{F})$ は，断層を表わし，（J）はその他の不連続面を表わす。 “位置”は，ブロックを構成する閉領域の重心座標である.

\section{5. 統計処理との比較}

不連続面の方向性に関する統計処理については，吉中 ら ${ }^{4)}$ にって提案されている。この方法は，Mathabの 方法に改良を加え，半球上正規分布でモデル化を行うも

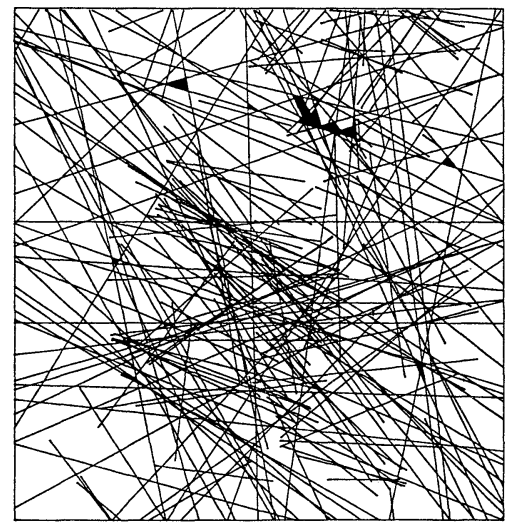

Fig. 10 Analytical results of removable blocks with average trace length 2-10 meters (Number of removable blocks $=29$ ).

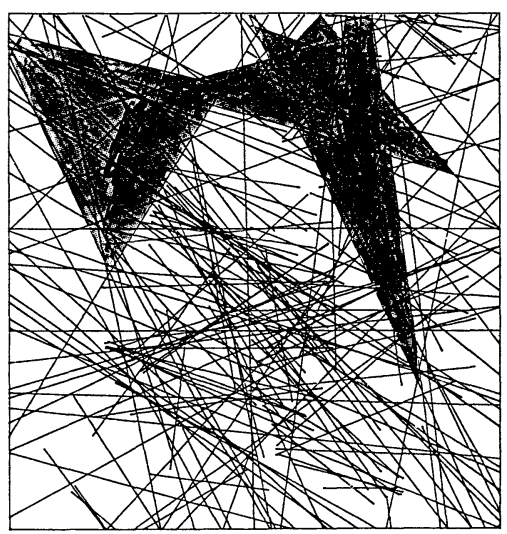

Fig. 11 Analytical results of removable blocks with trace length more than 70 meters (Number of removable blocks $=85$ ).

Table 5 Data of removable blocks in Fig. 10.

\begin{tabular}{|c|c|c|c|c|c|c|c|c|c|}
\hline 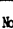 & \multicolumn{4}{|c|}{ 不连綿面 } & \multirow[b]{2}{*}{ CODB } & \multirow[b]{2}{*}{ ID } & \multirow{2}{*}{$\begin{array}{l}\text { 位 政 } \\
(\mathrm{X} / \mathrm{Y})\end{array}$} & \multirow[b]{2}{*}{ 移野方向 } & \multirow[b]{2}{*}{ 安全平 } \\
\hline $\mathrm{so}$ & D. D/Dip & D. D/Dip & D. D/Dip & D. D/Dip & & & & & \\
\hline & $65^{\circ} / 40^{\circ}(\mathrm{P})$ & $0^{\circ} / 40^{\circ}(\mathrm{P})$ & $300^{\circ} / 85^{\circ}(\mathrm{P})$ & $0 .()$ & 0011 & 12 & $43 / 112$ & $83^{\circ} / /$ & 1.41 \\
\hline 2 & $60^{\circ} / 60^{\circ}(\mathrm{P})$ & $140^{\circ} / 80^{\circ}(\mathrm{P})$ & $100^{\circ} / 35^{\circ}(\mathrm{P})$ & $0 \% 10^{\circ}()$ & 0001 & 3 & $139 / 167$ & $100^{\circ} / 125^{\circ}$ & 1.43 \\
\hline 3 & $120^{\circ} / 40^{\circ}(\mathrm{P})$ & $70^{\circ} / 40^{\circ}(\mathrm{P})$ & $312^{\circ} / 45^{\circ}(\mathrm{J})$ & $0 \% 10^{\circ}()$ & 0011 & 12 & $106 / 213$ & $95^{\circ} / 12 T^{\circ}$ & 1.37 \\
\hline & $70^{\circ} / 50^{\circ}(\mathrm{P})$ & $100^{\circ} / 35^{\circ}(P)$ & $316^{\circ} / 80^{\circ}(\mathrm{P})$ & $0^{\circ} / 0^{\circ}(1)$ & 0011 & 2 & $102 / 177$ & $100^{\circ} / 125^{\circ}$ & 1.43 \\
\hline 5 & $\left.65^{\circ} / 45^{\circ} \mathrm{J}\right)$ & $154^{\circ} / 65^{\circ}(\mathrm{J})$ & $280^{\circ} / 75^{\circ}(\mathrm{J})$ & $0 \% 10^{\circ}()$ & 0011 & 12 & $85 / 124$ & $89^{\circ} / 132^{*}$ & 1.28 \\
\hline 6 & $110^{\circ} / 60^{\circ}(\mathrm{P})$ & $70^{\circ} / 40^{\circ}(\mathrm{P})$ & $153^{*} / 62^{*}(\mathrm{P})$ & $0 \% 10^{\circ}()$ & 0001 & 23 & $174 / 65$ & & 1.39 \\
\hline & $300^{\circ} / 85^{\circ}(P)$ & $70^{\circ} / 40^{\circ}(\mathrm{B})$ & $153^{*} / 62^{*}(\mathrm{P})$ & $0 \% 10^{\circ}()$ & 1001 & 23 & $175 / 64$ & & 1.39 \\
\hline 8 & $12^{*} / 77^{(\mathrm{P})}$ & $100^{\circ} / 35^{\circ}(\mathrm{P})$ & $272^{\circ} / 80^{\circ}(\mathrm{P})$ & $0 \% 10^{\circ}()$ & 1011 & 2 & $71 / 187$ & $100^{\circ} / 125^{\circ}$ & 1.43 \\
\hline 9 & $320^{\circ} / 70^{\circ}(\mathrm{B})$ & $70^{\circ} / 40^{\circ}(\mathrm{P})$ & $153^{\circ} / 62^{*}(\mathrm{P})$ & $0 \% 10^{\circ}()$ & 1001 & 23 & $174 / 66$ & $88^{\circ} / 129^{\circ}$ & 1.39 \\
\hline 10 & $140^{\circ} / 80^{\circ}(\mathrm{P})$ & $100^{\circ} / 5 T(\mathrm{P})$ & $100^{\circ} / 35^{\circ}(\mathrm{P})$ & $0 \% 10^{\circ}()$ & 0001 & 3 & $40 / 167$ & $100^{\circ} / 125^{\circ}$ & 1.43 \\
\hline 11 & $140^{\circ} / 80^{\circ}(\mathrm{P})$ & $100^{\circ} / 35^{\circ}(\mathrm{P})$ & $94^{\circ} / 8 \mathrm{~T}(\mathrm{P})$ & $0^{\circ} / 0^{\circ}()$ & 0001 & 2 & $136 / 169$ & $125^{\circ}$ & 1.43 \\
\hline 12 & $314^{\circ} / 65^{\circ}(\mathrm{P})$ & $70^{\circ} / 40^{\circ}(\mathrm{P})$ & $100^{\circ} / 35^{\circ}(\mathrm{B})$ & $0 \% 10^{\circ}()$ & 1001 & 3 & $128 / 170$ & $/ 125^{\circ}$ & 1.43 \\
\hline 13 & $314^{\circ} / 65^{\circ}(\mathrm{P})$ & $73^{\circ} / 84^{\circ}(\mathrm{J})$ & $100^{\circ} / 35^{\circ}(\mathrm{P})$ & $0^{\circ} / 0^{\circ}()$ & 1001 & 3 & $126 / 171$ & $100^{\circ} / 125^{\circ}$ & 1.43 \\
\hline 14 & $314^{\circ} / 65^{\circ}(\mathrm{P})$ & $64^{\circ} / 85^{\circ}(\mathrm{J})$ & $100^{\circ} / 35^{\circ}(\mathrm{P})$ & $0^{\circ} / 0^{\circ}()$ & 1001 & 3 & $28 / 170$ & $100^{\circ} / 125^{\circ}$ & 1.43 \\
\hline 15 & $314^{\circ} / 65^{\circ}(\mathrm{P})$ & $100^{\circ} / 35^{\circ}(\mathrm{P})$ & $94^{\circ} / 8 T(\mathrm{P})$ & $0 \% 10^{\circ}()$ & 1001 & 2 & $31 / 169$ & $100^{\circ} / 125^{\circ}$ & 1.43 \\
\hline 16 & $280^{\circ} / 80^{\circ}(\mathrm{J})$ & $70^{\circ} / 40^{\circ}(\mathrm{P})$ & $153^{*} / 62^{*}(\mathrm{P})$ & $0 * 10^{\circ}()$ & 1001 & 23 & 64 & $129^{\circ}$ & 1.39 \\
\hline 17 & $320^{\circ} / 60^{\circ}(\mathrm{J})$ & $70^{\circ} / 40^{\circ}(P)$ & $153^{*} / 62^{*}(\mathrm{P})$ & $0^{*} / 0^{\circ}()$ & 1001 & 23 & $174 / 65$ & $29^{\circ}$ & 1.39 \\
\hline 18 & $84^{\circ} / 65^{\circ}(\mathrm{P})$ & $100^{\circ} / 35^{\circ}(\mathrm{P})$ & $337^{\circ} / 72^{*}(\mathrm{P})$ & $0 \% 10^{\circ}()$ & 0011 & 2 & $187 / 154$ & $100^{\circ} / 125^{\circ}$ & 1.43 \\
\hline 19 & $70^{\circ} / 40^{\circ}(\mathrm{P})$ & $114^{\circ} / 87^{\circ}(\mathrm{P})$ & $340^{\circ} / 90^{\circ}(\mathrm{P})$ & $100^{\circ} / 35^{\circ}(\mathrm{P})$ & 00101 & 4 & $124 / 176$ & $100^{\circ} / 125^{\circ}$ & 1.43 \\
\hline 20 & $70^{\circ} / 40^{\circ}(\mathrm{P})$ & $153^{\circ} / 62^{\circ}(\mathrm{P})$ & $85^{\circ} / 50^{\circ}(\mathrm{P})$ & $0^{\circ} / 0^{\circ}()$ & 0001 & 12 & $175 / 63$ & $88^{\circ} / 129^{*}$ & 1.39 \\
\hline 21 & $345^{\circ} / 80^{\circ}(\mathrm{P})$ & $73^{\circ} / 84^{\circ}(\mathrm{J})$ & $100^{\circ} / 35^{\circ}(\mathrm{P})$ & $0 \% 10^{\circ}()$ & 1001 & 3 & $123 / 171$ & $100^{\circ} / 125^{\circ}$ & 1.43 \\
\hline 22 & $340^{\circ} / 90^{\circ}(\mathrm{P})$ & $73^{\circ} / 84^{\circ}(\mathrm{J})$ & $100^{\circ} / 35^{\circ}(\mathrm{P})$ & $0 \% 10^{\circ}()$ & 1001 & 3 & $126 / 172$ & $100^{\circ} / 125^{\circ}$ & 1.43 \\
\hline 23 & $340^{\circ} / 90^{\circ}(\mathrm{P})$ & $64^{\circ} / 85^{\circ}(\mathrm{J})$ & $100^{\circ} / 35^{\circ}(\mathrm{P})$ & $0 \% 10^{\circ}()$ & 1001 & 3 & $127 / 171$ & $100^{\circ} / 125^{\circ}$ & 1.43 \\
\hline 24 & $33 T^{*} / 56^{*}(\mathrm{P})$ & $93^{\circ} / 45^{\circ}(P)$ & $100^{\circ} / 35^{\circ}(\mathrm{P})$ & $0.10^{\circ}()$ & 1001 & 3 & $149 / 164$ & $0^{\circ} / 125^{\circ}$ & 1.43 \\
\hline 25 & $337^{\circ} / 56^{\circ}(\mathrm{P})$ & $197^{\circ} / 40^{\circ}(\mathrm{P})$ & $100^{\circ} / 35^{\circ}(\mathrm{P})$ & $0 \% 10^{\circ}()$ & 110 & 3 & $150 / 164$ & $25^{\circ}$ & 1.43 \\
\hline 26 & $100^{\circ} / 5 T^{*}(\mathrm{P})$ & $159^{\circ} / 64^{\circ}(\mathrm{J})$ & $100^{\circ} / 35^{\circ}(\mathrm{P})$ & $0^{\circ} / 0^{\circ}()$ & 0001 & 3 & $143 / 167$ & $100^{\circ} / 125^{\circ}$ & 1.43 \\
\hline 27 & $95^{\circ} / 46^{\circ}(\mathrm{J})$ & $159^{\circ} / 64^{\circ}(\mathrm{J})$ & $100^{\circ} / 35^{\circ}(P)$ & $0 \% 10^{\circ}()$ & 0001 & 3 & $146 / 168$ & $100^{\circ} / 125^{\circ}$ & 1.43 \\
\hline 28 & $144^{\circ} / 64^{\circ}(\mathrm{J})$ & $64^{\circ} / 85^{\circ}(\mathrm{J})$ & $100^{\circ} / 35^{\circ}(\mathrm{P})$ & $0^{\circ} / 0^{\circ}()$ & 0001 & 3 & $128 / 172$ & $100^{\circ} / 125^{\circ}$ & 1.43 \\
\hline 29 & $144^{\circ} / 64^{\circ}(\mathrm{J})$ & $100^{\circ} / 35^{\circ}(\mathrm{P})$ & $94^{\circ} / 87^{\circ}(\mathrm{P})$ & $0 \% 10^{\circ}()$ & 0001 & 2 & $131 / 169$ & $100^{\circ} / 125^{\circ}$ & 1.43 \\
\hline
\end{tabular}




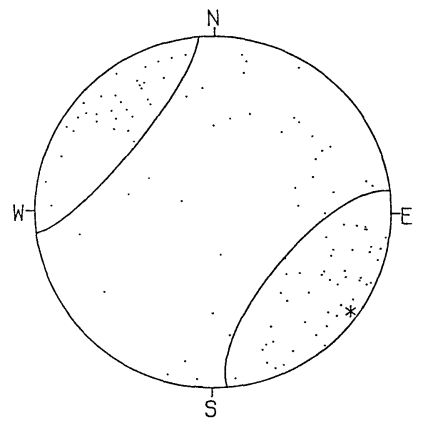

Fig. 12 Cluster division of faults (129 poles).

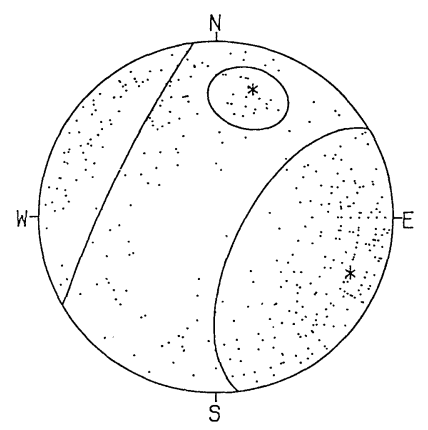

Fig. 13 Cluster division of discontinuities except of faults (493 poles).

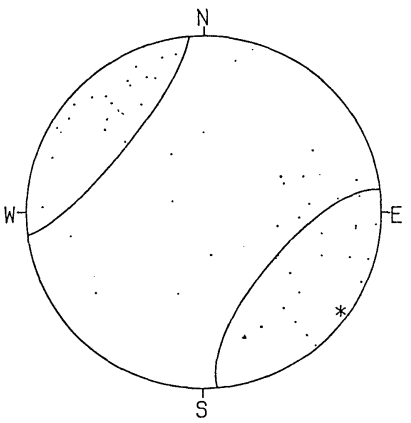

Fig. 14 Stereographic projection of faults obtained by the deterministic analysis.

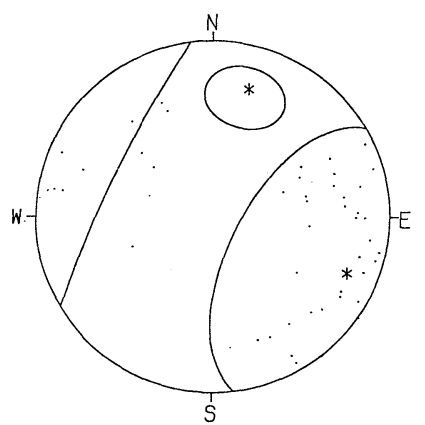

Fig. 15 Stereographic projection of discontinuities except of faults obtained by the deterministic analysis.

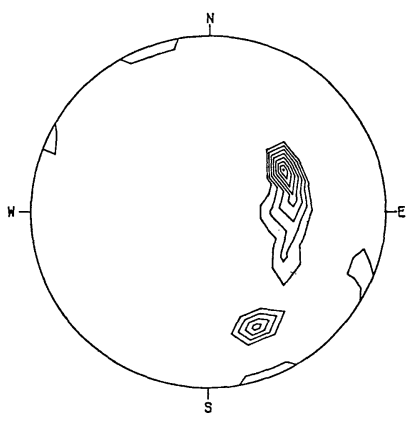

Fig. 16 Equi-density contour plot of the data in Fig. 14.

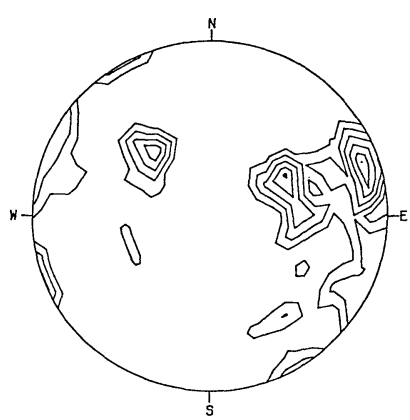

Fig. 17 Equi-density contour plot of the data in Fig. 15.
Table 6 Results of statistical analyses.

\begin{tabular}{|c|c|c|c|}
\hline & 断層 & \multicolumn{2}{|c|}{ その他の不連続面 } \\
\hline クラスターNo. & No. 1 & No. 1 & No. 2 \\
\hline \multirow{3}{*}{\begin{tabular}{cc} 
卓越方位 & \multicolumn{1}{c}{ 傾斜方位 } \\
傾 & 斜 \\
分布簕囲 $\quad \psi$ max
\end{tabular}} & $128.87^{\circ}$ & $116.11^{\circ}$ & $15.12^{\circ}$ \\
\hline & $85.55^{\circ}$ & $70.92^{\circ}$ & 60.19 \\
\hline & $46.44^{\circ}$ & $58.69^{\circ}$ & $16.35^{\circ}$ \\
\hline \multirow{2}{*}{ 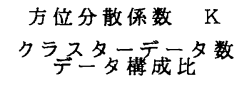 } & 8.46 & 7.91 & 68.18 \\
\hline & $\begin{array}{l}96 \\
74.4 \%\end{array}$ & $\begin{array}{r}239 \\
48.5 \%\end{array}$ & $\begin{array}{r}23 \\
4.7 \%\end{array}$ \\
\hline 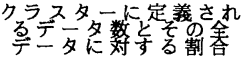 & $\begin{array}{l}96 \\
74.4 \%\end{array}$ & \multicolumn{2}{|c|}{$\begin{array}{l}262 \\
53.1 \%\end{array}$} \\
\hline
\end{tabular}

のである. $K$ をばらつきを表わす定数とし，中心から 角度 $\phi$ だけ離れたところの半球上正規分布の確率密度 関数 $f(\phi)$ は次式のようになる.

$$
f(\psi)=\frac{K}{2 \pi} \exp [K(\cos \psi-1)] \text {. }
$$

本研究の場合, デー夕数は 622 点であり調査横坑展開 図より傾斜/傾斜方位を読み取ったものである。この場 合, データ数が多く分布範囲が広いので, 断層とその他 の不連続面に分け, クラスタ一分割したものが Fig. 12, Fig.13である.ただし，これらのステレオ投影図は各
不連続面の法線を等面積投影したものである. 図中の実 線がその範囲，*印は卓越方位である．これらの図から 明らかなように，断層は1クラスター，その他の不連続 面は 2 クラスターに区分されることがわかる. Table 6 は，各クラスターごとの統計諸量である.

先の解析で求めた危険な移動可能ブロックを構成する 不連続面のステレオ投影図を, Fig. 14 に断層, Fig. 15 にその他の不連続面として示す。図中の実線の円は, 前 述の各クラスタ一の分布範囲を示している.この図は, 危険な移動可能ブロックとなった不連続面すべての点な ので同じ点が何回も重なっている場合がある. 確定論的 解析で危険な移動可能ブロックを構成する不連続面の分 布は, 断層とその他の不連続面とも統計処理の結果より 北方向，つまり，傾斜方位が小さい方向に危険な方向が 分布している. しかし, 各クラスターの分布範囲の内側 に集中点が存在している.また，Fig. 16, Fig.17には おのおののコンターマップを示す，同図は，危険な移動 可能ブロックの出現度数に一致している. よってこの図 より，危険な方向が把握できる。 


\section{6. 結 論}

以上に述べた不連続性岩盤斜面に対するブロック理論 の適用結果の考察から次のことがいえる.

（1）不連続面の分布位置の情報が得られる調査段階 にキーブロック解析を行うことにより, 移動可能ブロッ クの分布位置とその形状・寸法の情報を得ることができ る. しかし, 不連続面の連続性や不連続面のせん断強度 などの評価に不確実さを伴うので，この段階での解析成 果は移動可能ブロック分布の可能性に関する資料が求ま ると解釈すべきである.

（2）不連続面の多い岩盤では，計画掘削面上で安全 率の低いブロックが集合して不安定閉領域を構成するこ とが多い．種々のスケールの不安定閉領域を検索するこ とにより, 計画掘削面での不安定領域の分布を求めるこ とができる.

（3）計画掘削面上で任意の不安定な閉領域がより大 きい閉領域に包絡されている場合，すべり面を共有する 小さいブロックに適切な対策を行うことで全体を安定さ せることが可能となる。

（4）計画掘削面に安全率の低いブロックの閉領域が 存在する場合, 掘削面の岩盤内部への不安定ブロックの 連続性や分布を検索することにより, 当該ブロックの重 要性が検討できる。

（５） キーブロック解析は不連続面の調査精度の進捗 段階に応じて利用するのが適当である. 統計的な不連続 面の情報を主とする初期の露頭調查段階では, 移動可能 ブロックの平均的形状・法が得られる. 不連続面の分 布の位置の情報が加わる調査段階では, 危険ブロックの
概略の分布位置と寸法・形状が求まるのでより個別的な 支保対策が可能となる. 施工段階は不連続面分布が具体 的に示されるので，先の解析結果を踏まえた直接的な対 策が取れる。

（6）不連続面の分布特性 (方向・間隔・連続性, 等) は一般に大きくばらつく性質がある．確率論的解析の段 階ではそのばらつきを十分考慮した解析が必要である.

\section{参 考 文 献}

1) Goodman, R.E. and Shi, Gen-hua : Block Theory and Its Application to Rock Engineering, Prentice-Hall, 1985.

2）川本朓万・藤川富夫：岩盤掘削面におけるキーブロック 安定解析のシステム化について，土木学会論文集，第 346 号 / III-1, pp. 47 53, 1984.

3）大西有三・長野恵一・藤川富夫 : ブロック理論による不 連続性岩盤掘削時の安定性評価について，土木学会論文 集，第 364 号 / III -4, pp. 209 218，1985 年.

4）吉中龍之進・吉田 淳・藤田朝雄：岩盤不連続面の方向 に関するデータ処理システムの提案，第 42 回土木学会年 次学術講演会講演概要集 ( III), pp. 350 351, 1987.

5）吉中龍之進・吉田 淳・藤田朝雄 : 岩盤不連続面の方向 性に関する分布特性の評価とそのブロック理論への適用, 第 7 回岩の力学国内シンポジウム講演論文集, pp. 145 150, 1987.

6）吉中龍之進・藤田朝雄・大部正宏：岩盤斜面におけるブ ロック理論の適応に関する研究, 第 43 回土木学会年次学 術講演会講演概要集 (III), pp. 656 657, 1988.

7) Chan, L. Y. and Goodman, R.E. : Prediction of Support Requirements for Hard Rock Excavation Using Keyblock Theory and Joint Statistics, Proc. of 24th U.S. Sympo. on Rock Mech., pp. 857 872, 1984.

(1989.6.15・受付) 